\title{
Review of accounting and economic standards in predicting Stock returns in Tehran Stock Exchange
}

\author{
Sasan Amini ${ }^{1, *}$, Mohammad Nazaripour ${ }^{2}$, Mohamad Karimi Poya ${ }^{1}$ \\ ${ }^{1}$ Department of Agricultural Management, Hamedan Science and Research Branch, \\ Islamic Azad University, Hamedan, Iran \\ ${ }^{2}$ Department of Accounting, University of Kurdistan, Kurdistan, Iran \\ *E-mail address: Amini.Sasan66@gmail.com
}

\begin{abstract}
Share return is one of those complicated abstraction which is interested by investors and decision makers the share return prediction is a vital issue which has involved the financial analyzers mind to itself. Various theories include capital assets pricing model (CAPM), factorial models (FM), Arbitrage model, Technical model (TM), and fundamental analyses (FA) for purpose of share return prediction and recognition have been discussed. The share return fundamental analyze is a function of massive economical condition, Industry position, and particular conditions of the firm. The particular conditions of the firm are consist of financial position and performance which presented in the essential financial statement from. The accounting science acclaims it prepares useful information for decision makers, so one of the information usefulness criteria of accounting and economical information usefulness through return share choice for prediction. Communication creation between economical and accounting criteria is the other goal, thus in the case of this result obtaining it can use of economical and accounting analyses for economical return and value extraction. The research location zone includes of accepted firms in Tehran exchange market, the temporality zone is the gap between 1386 and 1390, too. The research is consist of two independent varieties (economical criteria and accounting criteria), dependent variety (share return). This research is consisting of a direct hypothesis and 6 indirect ones. in the consideration of presented statistical analyses and total summery of research hypothesis assessment, stood over research independent varieties meaningful relation with share return prediction in existing firm performance measurement in Tehran capital exchange market during 2007 and 2011 is existed, between this research proportion is return of assets, earning per share, economical add value ratio, retained earning ratio with positive quantity market add value with negative quantity which statistically shows a meaningful relation with active firms share return in Tehran market. The economical add value ratio has the biggest relation with the share return prediction. So the first hypothesis in this research is (return of assets ratio), secondly (earning per share), thirdly (economical add value), fourthly (market add value) and sixthly (retained earnings) being emphasized.
\end{abstract}

Keywords: Stock Returns; Accounting Standards; Economic Criteria; Fundamental Analysis; Capital Asset Pricing

\section{INTRODUCTION}

Nowadays, regarding the importance and increasing extension of capital markets in outfit and collection of small personal capital towards productive activities, identifying 
investor behaviors and affected variables on price and stock returns in these markets gained very importance. Some of the affected variables on stock market are due to financial information of economic entities that are extracted from these accounting system units; the effectiveness of this information is very complex and partly unknown. In addition, stock market is influenced by many parameters of macro-economic and non-economic market and many unknown variables, multiplying of affected factors on capital markets and their unknowing, caused uncertainty in investment. It is believed that stock prices are determined by some macro-economic variables (such as economic value added, market value added and residual income) and accounting variables (such as return on assets, return on equity, earnings per share ratio). So study on the effect of economic and accounting variables on stock returns can have an impact on how the stock is pricing. Much of it can meet the needs of investors and shareholders (Malekian and Asghary, 2006). In this study predicting stock returns according to accounting and economic standards has been studied.

\section{AN OVERVIEW OF THE THEORETICAL LITERATURE AND HISTORY OF RESEARCH}

Knowledge of accounting claimed that it provides useful information for decisionmakers, one useful standard of the accounting information is what it can predict. Using accounting information in decision-making, without its analysis, are not very effective and may even led to astray by the users, if the analysis, while their analysis can provide very valuable information for investors and help them for making conscious, rational decisions. Prediction plays an important role in economic decisions. At an enterprise level, investors, creditors, management and other users of financial statements can relied upon to self or others prediction, since most financial statements users do not directly access to financial information, inevitably rely on the provided prediction by management.

Johnny and Khodadadi (2011) examined the relationship between earnings and its components with stock returns. The results showed that companies with high earnings quality, positive returns and companies with low positive earning, obtain negative returns, so that in this course research companies which have the highest earning qualities could gain return more than 17 percent benefit from the companies that have lowest earning quality.

Shokri Habashi (2005) examined the realization rate of EPS investment companies with respect to forecasted EPS and its effect on stock prices on Tehran Stock Exchange between $78-82 \mathrm{~b}$. The results suggest that there is no significant relationship between the amount of adjusted earnings per share and stock price. But the relationship between the amount of realized earnings per share and stock prices are relatively low. Lashkari and Nawrozi (2010), have studied relationship between changes in balance sheet, earning and loss and trading volume to stock returns. According to the results, there is no significant relationship between trading volume and stock returns. Fatemi (2006), in a study titled "Forecasting stock returns using financial ratios" investigate the relationship between the ratio of earnings to price (E $/ \mathrm{P})$, book value to price ${ }^{1}(\mathrm{~B} / \mathrm{P})$, sale to $\operatorname{Price}^{2}(\mathrm{~S} / \mathrm{P})$, dividend per share to price ${ }^{3}(\mathrm{D} / \mathrm{P})$ and non-payment of future stock returns. In this study, a statistical method ${ }^{4}$ (PLS) was used to test the research hypotheses and research purpose; investigation the relationship between financial

\footnotetext{
${ }^{1}$ Book value to price

${ }^{2}$ Sale to price

${ }^{3}$ Dividend per share to price

${ }^{4}$ Pooled Least Squares
} 
variables related to earnings per share and return on equity was concerned. The statistic sample included 78 companies listed in Tehran Stock Exchange, which with this statistical method uses (PLS), individual relationship stock with its returns; in 78 to 83 were studied. The results showed that here is no significant relationship between the ratios $\mathrm{E} / \mathrm{P}$ and future stock returns and there is a significant relationship between the ratio $\mathrm{B} / \mathrm{P}, \mathrm{S} / \mathrm{P}, \mathrm{D} / \mathrm{P}$ and future stock returns.

Gan and Colleagues (2006), investigate the interaction between New Zealand stock index and a series of seven macroeconomic variables including inflation rates, exchange rates, gross domestic product, money supply, long and short-term interest rates and domestic retail oil price ${ }^{5}$. Johansson co-integration test results showed that there is a long-term relationship between New Zealand share price index and the economic variables. Granger causality test results also show that the index of stock prices is not for changes in economic variables. It is because of small New Zealand stock market compared to the stock markets of developed countries.

Lewellen (2004) published an article entitled predict returns using financial ratios. Predictive ability of 3 financial ratios DY (dividend yield); E /P, B /M as the independent variable for research that have common features are tested. Experimental tests showed that D /Y predicted market returns over the period 1946-2000, as well as a subset of the different period. The tests showed that the $\mathrm{B} / \mathrm{M}, \mathrm{E} / \mathrm{P}$ had a limited ability to predict the returns, otherwise DY yield greater power to predict stock returns. Lam (2002), in his study entitled "The relationship between the extent, ratio of return on equity, earnings to price ratio $(\mathrm{E} / \mathrm{P})$ and returns in Hong Kong stock market " investigate the relationship between these variables in Hong Kong during 1997-1984. Results of the study showed that there is a significant relationship between size, rate of return on equity and the ratio $\mathrm{E} / \mathrm{P}$ with stock returns.

Many studies have been done in relation to forecast stock returns, most of these studies have assumed that there is a linear relationship between the independent and the dependent variables such as: Comparison of the linear and nonlinear stock return - Canas and Yanvpvlvs (2001) explain that In this research, linear and nonlinear monthly returns prediction models are compared to the New York Stock Exchange. The results showed that the non-linear model better than linear model explains stock returns. Predictability of stock returns using MC Milian nonlinear models (2001) in this study yields a nonlinear relationship between variables such as interest rates, earnings and dividend ratio of stock price simple to a logarithmic model is estimated. The result showed that there is a nonlinear relationship between the above variable with stock returns, linear and nonlinear relationship between returns and financial ratios - Omran and Rajab (2004) in this study, linear and nonlinear relationship between financial ratios and stock returns using correlation analysis and multiple regressions were tested. Results of the linear model showed that the ratio of return on equity ratio is the only ratio that it can be used to predict stock returns, Therefore results of the nonlinear models show that the ratio return on equity and return on assets to predict stock returns is better than the other ratios, in general non-linear model better than linear model describes the behavior of return.

The statistical population consists of all listed companies in Tehran Stock Exchange that at least attended for two consecutive years in stock, which eventually using emissive systematic sampling (purposefully) 150 companies were selected. The independent variable of this study is stock return and the dependent variable is the economic and accounting standards.

\footnotetext{
${ }^{5}$ Domestic Retail Oil Price(ROIL)
} 
Kolmogorov test - Smirnov: This test is given for data to be normally. This test is just to determine the statistical method used to test the hypothesis. So that if the data are normally distributed, parametric test and if the data are not normally distributed, nonparametric test is used. Pearson's correlation analysis and simple linear regression:

\section{Correlation Research}

The major advantage of correlation method is that it allows researchers to measure many variables and simultaneously, calculate the internal correlation between them. Generally correlation is discussed on two criteria: 1$)$ the coefficient of determination $\left(\mathrm{R}^{2}\right)$

\section{Correlation coefficient}

The coefficient of determination $\left(\mathrm{R}^{2}\right)$ :

It is the most important standard that can be explained by the relationship between two variables $\mathrm{x}$ and $\mathrm{y}$. This value is always between zero and one:

Formula 1

$$
r^{2}=\frac{a \sum y+b \sum x y-n y^{-2}}{\sum y^{2}-n y^{-2}}
$$

Although a correlation coefficient of $50 \%$ does not mean that two or more variable have $50 \%$ common changes, but the squared correlation (coefficient of determination), show these changes. If the correlation coefficient between the two tests is $50 \%$, the two tests have common changes in $(50 \%)$ level, or 25 percent.

\section{Correlation coefficient}

If we take square root of coefficient determination, the result is correlation coefficient and we show it with $r$, that it can be positive or negative or zero. Correlation coefficients range is between $1+$ and 1 -, namely: If correlation coefficient is positive, indicate that movement is positive and If it is negative, implying a negative movement of independent variable to dependent variable. If the correlation coefficient is equal to $1+$ or $1-$ it is the indicative of complete dependence between dependent and independent variables, and if the correlation coefficient is zero, indicating that there is no correlation between dependent and the independent variable.

\section{Moment correlation (Pearson Correlation) - Product}

This method ${ }^{6}$ applied when studied variables (two variables that we want to calculate the correlation coefficient between them) are continuous. 
Formula 2

$$
r=\frac{C O V_{x . y}}{\sigma_{x} \sigma_{y}}=\frac{\frac{1}{N} \sum\left(x_{1}-\bar{x}\right)\left(y_{1}-\bar{y}\right)}{\sqrt{\frac{\sum\left(x_{1}-\bar{x}\right)^{2}}{N} \frac{\sum\left(y_{1}-\bar{y}\right)^{2}}{N}}}
$$

Using Pearson correlation coefficient test can find independent or connection between two variable. The Pearson correlation coefficient has a parameter and as it was said, as follows:

Formula 3

$$
r=\frac{C O V_{x, y}}{\sigma_{x} \sigma_{y}}
$$

According to the research variables and hypotheses and their correlation between them from Pearson correlation coefficient and t-test Student at $95 \%$ confidence level $(5 \%$ error level) for correlation meaningful test of two variables is used.

\section{FINDINGS}

Descriptive statistics for variables that include accounting and economic standards are presented in Table 1. Descriptive statistics is for 150 sample companies and for the period of 5 years $(2007-2011)$.

Table 1. Descriptive statistics of variables.

\begin{tabular}{|c|c|c|c|c|c|c|c|}
\hline & BAZDEH & ROA & ROE & EPS & EVA & MVA & DPS \\
\hline Mean & 33.48865 & 4.862493 & 21.55761 & 0.001508 & 25.53301 & 0.953548 & 0.045571 \\
\hline Median & 11.14628 & 5.996649 & 22.25902 & 0.000409 & 0.188600 & 0.151815 & 0.003433 \\
\hline Maximum & 820.1646 & 62.33153 & 1561.007 & 0.061373 & 3108.821 & 62.39639 & 2.664945 \\
\hline Minimum & -81.46160 & $66.86531-$ & $545.9492-$ & $0.029026-$ & $173.9040-$ & $61.52749-$ & $1.39 \mathrm{E}-06$ \\
\hline $\begin{array}{c}\text { Standard } \\
\text { deviation }\end{array}$ & 90.92950 & 16.26721 & 76.75852 & 0.006717 & 209.6451 & 6.118857 & 0.186179 \\
\hline Skewness & 4.626714 & -1.115935 & 9.728124 & 2.554113 & 11.45687 & 0.303621 & 8.450682 \\
\hline Elongation & 33.52551 & 6.556755 & 224.6259 & 22.97197 & 147.0058 & 44.95252 & 90.52233 \\
\hline Total & 25116.49 & 3646.870 & 16168.21 & 1.130839 & 19149.76 & 715.1607 & 34.17808 \\
\hline $\begin{array}{c}\text { Number of } \\
\text { observation }\end{array}$ & 750 & 750 & 750 & 750 & 750 & 750 & 750 \\
\hline
\end{tabular}


In this study Kolmogorov - Smirnov test in relation to normality distribution of data is used. In this test, the null hypothesis is defined as the data are normally distributed. Table 2 presented Kolmogorov - Smirnov test.

Table 2. Kolmogorov - Smirnov test to survey normality of the dependent variable.

One-Sample Kolmogorov-Smirnov Test.

\begin{tabular}{|c|c|c|c|c|c|c|c|}
\hline & lnbazdeh & lneps & lndps & lneva & lnmva & lnroe & lnroa \\
\hline & & & & & & & \\
$\mathrm{N}$ & 486 & 06 & 750 & 586 & 521 & 593 & 666 \\
Normal & 3.3257914 & 7.3746182 & 5.6761210 & 6.9026886 & 8.6277146 & 1.8912967 & 3.0666845 \\
$\begin{array}{c}\text { Parametersa, } \\
\text { b Mean }\end{array}$ & $4861364 \mathrm{E}$ & $8053815 \mathrm{E}$ & $6497787 \mathrm{E}$ & $3518150 \mathrm{E}$ & $0931499 \mathrm{E}$ & $5036587 \mathrm{E}$ & $7972702 \mathrm{E}$ \\
& 0 & 0 & 0 & -1 & -1 & 0 & 0 \\
Most Extreme & 1.4809978 & 2.0015286 & 2.3885640 & 2.7329691 & 2.0754712 & 1.2351993 & 9.7750248 \\
Differences & 27578617 & 11149170 & 54150168 & 60742316 & 46171960 & 40743953 & 62741519 \\
Absolute & $\mathrm{E} 0$ & $\mathrm{E} 0$ & $\mathrm{E} 0$ & $\mathrm{E} 0$ & $\mathrm{E} 0$ & $\mathrm{E} 0$ & $\mathrm{E}-1$ \\
& & & & & & & \\
Positive & .085 & .056 & .023 & .063 & .047 & .105 & .104. \\
Negative & & & & & & & .063 \\
Kolmogorov- & .047 & .030 & .023 & .063 & .020 & .063 & .069 \\
Smirnov Z & -.085 & -.056 & -.020 & -.050 & -.047 & -.105 & -.104 \\
Asymp. Sig. & 1.365 & 1.369 & .629 & 1.518 & 1.078 & 1.327 & 1.234 \\
(2-tailed) & .052 & .077 & .823 & .070 & .195 & .060 & .063 \\
\hline
\end{tabular}

As can be seen in Table 2, all significance level of the variables are greater than $5 \%$ and the null hypothesis based on the normality of data distribution is accepted.

Test for multicollinearity between variables:

In this study a linear test, using Pearson correlation ${ }^{7}$ coefficient will be done. The results of the correlation matrix will be interpreted according to the following rule:

If $\mathrm{r}$, is greater than $90 \%$ there is many and high correlation between the two variables.

1) If $r$, is between $70-90 \%$, there is a high correlation between the two variables.

2) If $r$, is between $40-70 \%$, there is a moderate correlation between the two variables.

3 ) If $r$, is between $0-40 \%$ there is a weak correlation between the two variables.

The correlation matrix is presented in Table 3.

\footnotetext{
${ }^{7}$ Pearson correlation coefficent
} 
Table 3. Correlation matrix between variables.

\begin{tabular}{|c|c|c|c|c|c|c|c|}
\hline & BAZDEH & ROA & ROE & EPS & EVA & MVA & DPS \\
\hline BAZDEH & 1 & & & & & & \\
\hline ROA & 0.01951918125992706 & 1 & & & & & \\
\hline ROE & 0.00097818564671355 & $0.00324853388347-$ & & & & & \\
\hline EPS & 0.03315662178865009 & 0.06696782219647 & $0.015195438345966-$ & 1 & & & \\
\hline EVA & $0.04647132707869131-$ & $0.00229838568940-$ & $0.010032626313135-$ & 0.10807870991636 & 1 & & \\
\hline MVA & 0.01548960132104541 & 0.00882327449178 & 0.0128033440497428 & 0.03997561445011 & 0.01069233712 & 1 & \\
\hline & 0.06735772282105204 & 0.01597411205610379 & 0.05473391110518949 & 0.22138414647954 & 0.0116515534 & 0.26034531412 & 1 \\
\hline
\end{tabular}

Since the correlation coefficient between the variables is less than $40 \%$, thus there is no multicollinearity between variables.

Independence of observations:

In this study, to assess the independence of the observations and their lack of correlation between the explanatory variables Dorbin Watson statistic is used. If this statistic was between 1.5 and 2.5 would be no correlation between the errors. Dorbin Watson statistic were calculated for all regression models that show this number is between $(1.5,2.5)$ and proves the lack of correlation in the regression model elements.

\section{Determined the method of using combined data}

Before using the combined data, primarily should determine that there is a need into taking account the panel structure of the data (specifically differences or special effects of the company) or integrate data from different companies (Pooling) and it can be used in estimating the model. Therefore, to estimate the suitable model, Lymr test to decide about rejection and acceptance of the equality of specific fixed companies effects and finally choosing the classic method or methods of data panel is used. So if the base of calculated significance level is smaller than $5 \%$ the assuming $\mathrm{H} 0$ is rejected and the rejection of null hypothesis means that the width of the origin of the levels (companies) are different and using pooling (OLS) is inconsistent, then it will not work and therefore should pay attention to panel model results. In the second stage to estimate whether the fixed or random effects model should be considered, the Hausman test is used and this test examine the following hypotheses:

H0: Consistent estimates of random effect

\section{H1: Consistent estimates of fixed effect}

If the calculated significance level of test is less than $5 \%$, so assuming $\mathrm{H} 0$ is rejected and this means that the best estimation is a fixed effects method. In Table 4 and 5 Lymr and Hausman test results are shown.

Table 4. Lymr test results for selecting pooling or panel combination method.

\begin{tabular}{|c|c|c|c|}
\hline Test results & p-value & The null hypothesis & model \\
\hline $\begin{array}{c}\text { H1 is proved. } \\
\text { pantegrat method or }\end{array}$ & 0.0000 & $\begin{array}{c}\text { Companies special } \\
\text { effects are not } \\
\text { significant }\end{array}$ & 1 \\
\hline
\end{tabular}

As can be seen in Table 4 at confidence level $95 \%$ of the null hypothesis is equal to all companies special effects in all models are unverified and means that in this model companies 
special fixed effects is different from other companies and can therefore estimate these models with huddle data related to different companies and classical method (panel).

In the second stage to determine whether model fixed effects method or random effects is used, the Hausman test is considered. This test examined the following hypotheses:

Table 5. Hausman test results for selecting fixed and random effects method.

\begin{tabular}{|c|c|c|c|}
\hline Test results & p-value & Null hypothesis (H0) & model \\
\hline $\begin{array}{c}\text { H1 is proved, fixed } \\
\text { effects are select }\end{array}$ & 0.0000 & $\begin{array}{c}\text { Consistent estimates of } \\
\text { random effect }\end{array}$ & 1 \\
\hline
\end{tabular}

Since the calculated significance level from this test is less than 5 percent. So assuming $\mathrm{H} 0$ is rejected and it is concluded that the best estimation is a fixed effects method.

Secondary research hypotheses test results

Generally secondary research hypotheses test results is shown in Table 6 and 7. In order to investigate the influence of all variables simultaneously for 6 foregoing hypotheses described from regression model, $\underline{\text { OLS }}$ was used (OLS).

Table 6. Regression model coefficients of OLS (OLS).

\begin{tabular}{|c|c|c|c|}
\hline Model component & coefficient & t-statistic & Significant level \\
\hline Fixed amount & 0.166127 & 1.524127 & 0.128 \\
\hline Rate of return on assets & 0.055747 & 4.034861 & 0.0001 \\
\hline $\begin{array}{c}\text { Rate of return on } \\
\text { equity }\end{array}$ & 0.023078 & 1.099080 & 0.272 \\
\hline Earnings per share & 0.128788 & 0.942752 & 0.3466 \\
\hline $\begin{array}{c}\text { Economic value added } \\
\text { ratio }\end{array}$ & 0.020461 & 2.339887 & 0.0199 \\
\hline $\begin{array}{c}\text { Market value added } \\
\text { ratio }\end{array}$ & $5.310-$ & $2.172044-$ & 0.0306 \\
\hline Earning remains ratio & 0.411314 & 7.93391 & $0 / 000$ \\
\hline
\end{tabular}

Table 7. All significant OLS model test.

\begin{tabular}{|c|c|c|c|c|}
\hline $\begin{array}{c}\text { Dorbin Watson } \\
\text { statistic }\end{array}$ & Significant level & F statistic & $\begin{array}{c}\text { Adjusted } \\
\text { coefficient of } \\
\text { determination }\end{array}$ & $\begin{array}{c}\text { Coefficient of } \\
\text { determination }\end{array}$ \\
\hline 0.260552 & 0.246053 & 17.97038 & $0 / 000$ & 25202 \\
\hline
\end{tabular}

According to the above table, the final model is arranged as follows:

$\mathrm{Yi}, \mathrm{t}=0.166127+0.055747^{X_{i, t 1}+0.020461} X_{i, t 4}-5.310^{X_{i, t} 6}+0.411314 X_{i, t 6}$ 
According to Table 6, the significance level rate of return on assets variables, economic value added ratio, market value-added ratio benefit ratio remains at $95 \%$ level of confidence is significant and according to the amount of their t- statistic, effect coefficients and the direction of effect is confirmed. That means relation, market value-added ratio with current year return is negative. And the relationship between the rate of return on assets variables, economic value added ratio, the ratio of residual income with stock returns in current year return is positive and direct. In general, the results of simultaneously performing show a significant effect of 4 variables, rate of return on assets, economic value added ratio, market value added ratio, and the ratio of residual income is based on the current year return. Contained results in Table 7 is approximately $26 \%$ of the variation in results of current year stock return is explained by 4 foregoing variables. Dorbin Watson statistic also as a lack of correlation variance, indicates not independent statements values. That Dorbin Watson statistics has been calculated for regression model. Which shows the values is between (1.5, 2.5 ) and it proves the absence of correlation in the component of regression model.

Panel Data Model (PANEL DATA)

In this study, data adornment is data integration (Pooled Data). And to estimate the model both random and fixed effects are used, and finally with appropriate tests, the results will be interpreted and evaluated as follows.

The results of the estimation model using fixed effects, in this method, assuming constant terms in the equations are estimated with fixed effects and the results obtained are as follows.

Table 8. Summary of panel data models with fixed effects.

\begin{tabular}{|c|c|c|c|}
\hline Model components & coefficient & T statistic & Significant level \\
\hline Fixed amount & 33.25235 & 12.62732 & 0.0000 \\
\hline Rate of return on assets & 0.133500 & 20.984755 & 0.0251 \\
\hline $\begin{array}{c}\text { Rate of return on } \\
\text { equity }\end{array}$ & 0.005135 & 0.269589 & 0.7876 \\
\hline Earnings per share & 1068.923 & 1.934878 & 0.0034 \\
\hline $\begin{array}{c}\text { Economic value added } \\
\text { ratio }\end{array}$ & 0.020018 & 4.656927 & 0.0000 \\
\hline $\begin{array}{c}\text { Market value added } \\
\text { ratio }\end{array}$ & $0.667459-$ & $2.411677-$ & 0.0161 \\
\hline Earning remains ratio & 44.74762 & 2.666391 & 0.0078 \\
\hline
\end{tabular}

Table 9. All significance test model with fixed effects.

\begin{tabular}{|c|c|c|c|c|}
\hline $\begin{array}{c}\text { Dorbin Watson } \\
\text { statistic }\end{array}$ & Significant level & F statistic & $\begin{array}{c}\text { Adjusted } \\
\text { coefficient of } \\
\text { determination }\end{array}$ & $\begin{array}{c}\text { Coefficient of } \\
\text { determination }\end{array}$ \\
\hline 1.870546 & $0 / 000$ & 5.937829 & 0.461848 & 0.474374 \\
\hline
\end{tabular}


In order to investigate the simultaneous effect of variants described in 6 items foregoing hypotheses, the regression model using least squares, generalized (using fixed effects) was used according to Table 8 , the significance level variable rate of return on equity ratio, earnings per share, economic value added, market value added, residual income is significant at $95 \%$ level of confidence and with regard to t-statistics their coefficient effects and effect direction is confirmed, that the relationship between the ratio of earnings per share, market value added and rate of return on equity ratio with this year stock returns is negative (inverse) and relationship of economic value added, residual income variables with current year stock returns is direct and positive. In general, the simultaneous implementation variables results show a significant effect of 5 variable rate of return on equity ratio, earnings per share, economic value added, market value added, residual income on current year stock returns. The results listed in Table 9, approximately $47 \%$ of the variation in stock returns by 5 year variable is explained by the foregoing Dorbin Watson statistic also indicates a lack of variance correlation values are not independent statements that confirm the improved Dorbin Watson statistic was calculated for the regression model which indicates the number between $(5 / 1,5 / 2)$, lack of correlation between the component model prove the above model.

\section{The results of the random effect model}

In this case, the model has been estimated with the assumption that sentences are consistent with a random distribution, and the results are as follows.

Table 10. Summary Results of panel data models with random effects.

\begin{tabular}{|c|c|c|c|}
\hline Model components & coefficient & T statistic & Significant level \\
\hline Fixed amount & 33.79474 & 8.971314 & 0.0000 \\
\hline Rate of return on assets & 0.093623 & 0.454106 & 0.6499 \\
\hline $\begin{array}{c}\text { Rate of return on } \\
\text { equity }\end{array}$ & 0.008062 & 0.184507 & 0.8537 \\
\hline $\begin{array}{c}\text { Earnings per share } \\
\begin{array}{c}\text { Economic value added } \\
\text { ratio }\end{array}\end{array}$ & 766.1382 & 2.486023 & 0.0377 \\
\hline $\begin{array}{c}\text { Market value added } \\
\text { ratio }\end{array}$ & $0.023396-$ & $2.455974_{-}$ & 0.0458 \\
\hline Earning remains ratio & $44.39255_{-}$ & 2.980765 & 0.0270 \\
\hline
\end{tabular}

Table 11. All significant test model with random effects.

\begin{tabular}{|c|c|c|c|c|}
\hline $\begin{array}{c}\text { Dorbin Watson } \\
\text { statistic }\end{array}$ & Significant level & F statistic & $\begin{array}{c}\text { Adjusted } \\
\text { coefficient of } \\
\text { determination }\end{array}$ & $\begin{array}{c}\text { Coefficient of } \\
\text { determination }\end{array}$ \\
\hline 1.729263 & $5 / 555$ & 2.430340 & 0.303435 & 0.311419 \\
\hline
\end{tabular}

As can be seen, in this model economic value added ratio, market value added ratio, residual income ratio variables are per share earnings again, which was statistically significant and all of their $\mathrm{t}$ - statistic number are larger than 2 and with 95 percent confidence have 
significant relationship with current year stock returns variables. But in this model, the value of the adjusted coefficient of determination equal to $316 / 0$ and thus approximately $31 \%$ of the behavior of stock returns is explained by these 4 variables. F statistics and also significance level with $99 \%$ confidence show that all of the model coefficients are significant and correct. Dorbin Watson statistic is near to 2, and so there is no serial correlation in the model. But the main question here is, finally, which of these two models is correct and attributable, therefore it is necessary with appropriate tests do this matter and continue it.

\section{Husmann test}

To check whether fixed or random effects are constant terms, we use the Husmann test. As can be seen in below table X2 statistic value (chi-square) equal to $7.150944 \mathrm{P}-$ Value $=$ $0 / 000$. Therefore, based on computed statistics, the constant terms are fixed effects. Therefore, this equation can be considered in the state of fixed effects, and describe again.

Table 12. Husmann test.

\begin{tabular}{|c|c|}
\hline Hausman test & Random Effect \\
\hline Chi-square & 7.150944 \\
P-value & $0 / 000$ \\
\hline
\end{tabular}

Briefly, as it was shown from these ratios, rate of return on equity ratio, earnings per share, economic value added, earnings per share, residual income ratio with positive coefficient and market value added is the negative coefficient that with companies' stock returns active in Tehran stock Exchange show a statistically significant correlation.

\section{DISCUSSION AND CONCLUSIONS}

Investors are always urging to increase their capital day to day and maximizing it and therefore are looking for investment opportunities that can create more wealth for them. To achieve this purpose, they need the tools and criteria for identifying and measuring the potential value of each investment opportunities. These criteria must be sufficiently reliable to enable investors to make their decisions based on them and spend their capital in commercial activities, hence the knowledge of accounting and financial management com to help investors to assist them in their decisions. In this study it was tried the ability of accounting and economic standards in predicting stock returns were examined. The original data of this study includes stock returns, accounting standards (return on assets, return on equity, earnings per share ratio) and economic standards (economic value added, market value added and residual income) for the 150 companies in Tehran Stock Exchange since 2007-2011. To test research hypotheses the multiple regression using panel data for the period 2007-2011, and to analysis multivariate regression $\mathrm{F}$ test statistic, $\mathrm{T}$ statistic, Dorbin Watson statistic (DW) to investigate the association between the independent variable with dependent variable in all listed companies are paid and specified.

Overall results of this study suggest that among the rates of this study, return on asset ratios, earnings per share ratio, economic value added ratio, residual income ratio with a positive coefficient and market value added is a negative coefficient. That statistically with active companies stock returns in Tehran Stock show significant relationship. 
Economic values added also have the highest association with predicting stock returns. Thus the first hypothesis of this study (rate of return on assets), third (Earnings per share ratio), fourth (economic value added), fifth (market value added) and sixth (residual income) is approved. Considering above facts the main hypothesis of this study, namely: stock returns using economic and accounting standards is responded. Since 5 of the six standards of economic accounting have been approved, so answer of the main hypothesis is positive, we can say that, stock returns using economic and accounting standards can be predicted. Results of the study correspond to, Lam (2002) that investigated the relationship between variables (size, rate of return on equity, earnings to price (E / P) to stick return) in Hong Kong during 1997 -1984. Also the results of this survey are consistent with Chan et al (1991) research. Of course, considerations of these findings should also be regarded. For example, the impact of political events, including economic sanctions on market atmosphere, which causes price volatility and leading to a significant gap between intrinsic value and market stock. Therefore a study regarding the role of non-financial factors that affect stock returns is recommended, such as economic, social, political and cultural factores. Similar studies for individual companies using or Quarterly Reports or using Lachyt models or fuzzy models and artificial intelligence should be carried out.

\section{References}

[1] Fatemi M. (2006). The role of accounting information in predicting the underlying stock returns. Department of Management, Allameh Tabatabai University, doctoral thesis.

[2] Shokri Habashi R. (2005). Comparative evaluation of the explanatory power of residual income and abnormal earnings growth in the value of the company, MS Thesis, University of Shiraz, the tips Hamid Mahmoud Abadi

[3] Johnny J., Khodadadi G. (2011). The Relationship between Economic Value Added and the dividend per share of the stock market value of listed companies in Tehran Stock Exchange clinic, MS Thesis, University of Mazandaran.

[4] Malekian N., Asghary A. (2006). The effect of macroeconomic variables on stock price indices, Master Thesis in Economics, Allameh Tabatabai University.

[5] Lashkari H., Nawrozi Z., Journal of Economic Studies 11 (2010) 121-130.

[6] Mehregan N. (2009). Eviews Guide to Econometrics, Tehran, Faculty of Economic Sciences.

[7] Gan C., Colleagues (2006). Earnings Management, Audit tenure and auditor changes: does mandatory auditor rotation improve audit quality"? Accounting Department Universita Bocconi Milan, Italy and Instituto de Empresa Business School, Madrid, Spain.

[8] Saeedi A., Moghadasian I., Stock Exchange Quarterly 9 (2010) 5-24.

[9] Mohsen Mehrara, Hamid Abrishami, Mostafa Boroujli, Mahan Amin, International Letters of Social and Humanistic Sciences 11 (2013) 76-83.

[10] Bahram Meihami, Zeinab Varmaghani, Hussein Meihami, International Letters of Social and Humanistic Sciences 11 (2013) 91-99 
[11] Mohsen Mehrara, Zabihallah Falahati, Nazi Heydari Zahiri, International Letters of Social and Humanistic Sciences 10(1) (2014) 26-35.

[12] Morteza Ziaee, International Letters of Social and Humanistic Sciences 10(1) (2014) 36-43.

[13] Gholamreza Jandaghi, Hamid Reza Irani, Ehssan Jandaghi, Zeinab Sadat Mousavi, Maryam Davoodavabi, International Letters of Social and Humanistic Sciences 15(1) (2014) 78-83.

[14] Mohammadbagher Mohammadinejad Pashaki, Reza Tehrani, Hamid Zarea, Hossein Khanifar, Gholamreza Jandaghi, International Letters of Social and Humanistic Sciences 18 (2014) 8-13. 